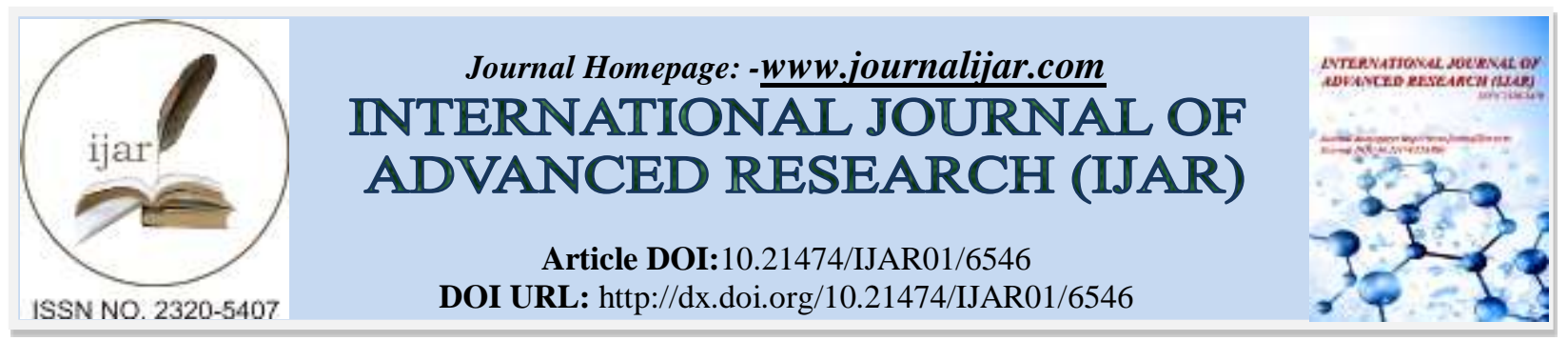

RESEARCH ARTICLE

\title{
THE IMPACT OF LEADERSHIP, PERSONALITY, AND REWARD TO THE PERFORMANCE OF JUNIOR HIGH SCHOOL TEACHERS IN PEKANBARU CITY.
}

\section{Muhammad Haris, Mukhneri Mukhtar and Nurhattati.}

\section{Manuscript Info}

(.........................

Manuscript History

Received: 20 December 2017

Final Accepted: 22 January 2018

Published: February 2018

Keywords:-

leadership, personality, reward, and performance.

\section{Abstract}

The purpose of this research is to study the impact of leadership, personality and reward to the performance of Junior High School teachers in Pekanbaru City.This research used quantitative approach with survey method. The population in this research is 255 certified teachers of Junior High School in Pekanbaru City.The results of this study indicate; (1) Positive Direct Impact of Leadership on Performance (2) Positive Direct Impact of Personality on Performance (3) Positive Direct Impact of Reward on Performance. Thus, the improvement of teacher performance can be well achieved if there is strong impact from leadership, personality, and reward that are well built.

Copy Right, IJAR, 2018,. All rights reserved.

\section{Introduction:-}

Teachers are an important component in the world of education; therefore, more attention needs to be given to support their performance in order to create qualified teachers. Teachers also play an important role in the world of education, especially in the formal sector in schools. They ensure the success of learners, especially in terms of teaching and learning process that is usually carried out in school. The performance success which is shown by teachers is influenced by their surrounding. Therefore, their surrounding, especially in this case school, such as the principal, should be able to motivate and empower teachers to create good performance and be able to play a role as professional teachers in addition to the teachers who must be able to improve themselves in the quality of their own work.

Given the important role of teacher performance in the quality of education and human resource in Indonesia, it is only natural that the reality of the low Human Development Index (HDI) and the low quality of education in Indonesia is the result of low performance of teachers.

Specifically in Pekan Baru City, so far the performance of teachers have not exhibited maximum results. Based on the report of Junior High School supervisors of Pekan Baru City Year 2012, it was obtained that (1) the ability of planning/prepararing learning device was 70\%, (2) organizing in learning was 60\%, (3) implementation of learning was $75 \%$, (4) assessment of learning was $65 \%$, and (5) evaluation of learning outcomes was $60 \%$. Such data, when being averaged shows, that more than $70 \%$ of junior high school teachers in Kota Pekan Baru have not mastered or been informed about process standards in accordance with Ministerial Decree Number 41 Year 2007.

The data above is reinforced by the Tribun Pekan Baru report, where the average score of Teachers' Competence Test in Pekan Baru City was only 40.37 whereas the standard value of TCT is 70, with the highest score of 72 and the lowest value of 0 . From the TCT result, most participants are weak on pedagogic materials, where none of the 
participants were able to reach correctness up to 30 pedagogic items. There were even teachers whose pedagogic value was 0.

Through interviews conducted with the principal at SMPN Kota Pekan Baru, the principal stated that; (1) there are still teachers who do not come to school on time, (2) there are still teachers who have not prepared learning tools such as RPP, (3) there are still very rarely teachers who take part in coaching on extracurricular activities, (4) there are limited teachers who are willing to nurture other teachers both cognate and non-cognate teachers, so teachers' ability is not evenly distributed, and (5) there are still teachers who do not care about the progress of the school. ${ }^{1}$

If this condition is ignored and no improvement is carried out, it can be ascertained that teacher performance will degrade and will impact on students' achievement. There are several aspects for the performance of teachers in schools to run properly, namely through increased leadership of the principal, personality and rewards.

Teachers play an absolute role in determining the quality of education and graduates created from a school. This means that if the teachers performing tasks successfully realize their tasks with high quality, then it indirectly affects the process of implementation of quality learning so that it automatically gives impact on the increasing quality of graduates and grade of the school itself. Darling \& Hammond (2000: 1) from Stanford University conducted a study showing that the factor of teachers quality has a significant correlation to student achievement. It is similar to the research of Schacter (2006: 2), which explains that the performance of teachers is a very important input variable in improving students' achievement.

From a number of problems above the performance of teachers is an important factor in improving the quality of learners; however, teacher performance is influenced by many factors, both from within and from outside the teachers themselves. This research is an effort to get a picture about the performance of teachers and influencial factors in improving the quality of junior high school teachers, especially in the city of Pekanbaru.

\section{Performance:-}

Performance has a broader meaning, it is not just stated as work result, but also as how the work process takes place. Performance is about doing the work and the results achieved from the worker. Performance is about what to do that has a strong relationship with the organization's strategic goals, customer satisfaction and provide economic contribution. According to Steve M. Jex (2002: 88) performance ie, "job performance is a deceptively simple term. At the most general level it can be defined simply as all the behaviors employees engage in while at work". Performance is a reflection of employee's behavior in doing his work to achieve organizational goals. How organizations value and treat their human resources will influence their attitudes and behaviors in carrying out the performance.

Furthermore, Leslie W. Rue, and Lloyd L. Byars (2008: 216) define the performance as follows, "job performance is the net of an employee's effort as modified by abilities and role (or task) perceptions. Thus, performance in a given situation can be viewed as resulting from the inter-relationship". Performance is one of an employee's effort related to an employee's ability, an employee's role in work or obligation of an employee perceived in the form of action in work; thereby performance in certain situation can be seen as result of one's relation with work. Therefore, the measurement of teacher performance in addition to the main task, is also needed to be seen from the academic agenda and professional development undertaken by teachers.

From the above description it can be synthesized that performance is the work show of a person in carrying out the work within a certain time, work behavior indicators, actions in work, work procedures and work methods.

\section{Leadership:-}

Influencing activity is the core of leadership, in order for a person to be an effective leader, he must be able to influence others to be willing to run orders, to support and implement policies. To understand what makes effective leaders requires complex analysis on networks of power relations and influencing processes found in all organizations.

Jason A. Colquitt, Jeffery A. Lepine, and Michael J. Wesson (2015:464) defines leadership as follow, "leadership is defined as the use of power and influence to direct the activities of followers toward goal achievement". Leadership

\section{${ }^{1}$ The Results of Interview with The Headmaster}


is the power and influence to run the employees activities to the goals that want to be achieved by the organization. Leadership is a process where a leader influences his subordinates in ways that are not pushful to achieve a predetermined goal.

Robert J.Thierauf(2012:490) et alstated "leadership,....., may be defined as a way of stimulating and motivating subordinates to accomplish assigned tasks." So a leader must also be able to move his subordinates in the sense of creating group or individual activities to achieve the goals set. G. L. Freeman (2013: 40), et al says "leadership is the ability to create group action toward an organizational objective with maximum effectiveness and cooperation from each individual."

Furthermore John R. Schemerhorn, JR, Richard N. Osborn, Mary Uhl-Bein, and James G. Hunt (2012: 306) define leadership as follows, "leadership is the process of influencing others and the process of facilitating individual and collective effors to accomplish shared objectives". Leadership is a process of influencing others and the process of facilitating collectively in achieving common goals.

John W. Newstrom (2015: 179) defines leadership as follows, Leadership is the process of influencing and supporting others to work enthusiastically toward achieving objectives. It is the critical factor that helps an individual or a group identify its goals and then motivates and assists in achieving the stated goals.

Autocratic leadership is suitable for members with low competence but high commitment. Coaching leadership is suitable for members who have moderate competence and low commitment. Democratic leadership is suitable for members who have high competencies with varying commitments. Meanwhile, free control leadership is suitable for members who have competence and high commitment.

From the above description it can be synthesized that leadership is one's activities in influencing others to achieve organizational goals efficiently and effectively, with indicators: to facilitate subordinates, to direct subordinates, to negotiate with subordinates.

\section{Personality:-}

Personality is a reflection of identity that leads to the behavior of a person in everyday life. Personality can be changed and can also depend on one's perception and mindset. Personality is defined by personality experts based on specific concepts contained in certain theories that are considered adequate to describe or understand the behavior of individuals as a whole.

Kreitner and Kinicki (2010: 133), defines personality as follows: Personality is defined as the combination of stable physical and mental characteristics that give the individual his or her identity. These characteristic or traitsincluding how one looks, thinks, acts, and feels-are product of interacting genetic and environmental influences. Personality is a combination of stable physical and mental characteristics that give identity to the individual. These characteristics or attributes include the person's appearance, thoughts, actions, and feelings that are products of genetic and environmental influences that interact with each other.

Based on the description of the concept of personality above, it can be synthesized that personality is all the shades of behavior and characteristic that can be predicted in a person or more and can be seen from the outside, which are used to react and adjust to the stimulus so that the pattern of behavior is a unity functional characteristic for the individual, measured using the following indicators: (1) confidence; (2) establishing working relationships; (3) tranquility level; (4) enthusiasm about togetherness; (5) freedom to express emotions.

\section{Reward:-}

Reward is the amount of payment received and the level of conformity between the payment and the work performed. In the organization there is the term incentive, which is a reward in the form of material or non-material given by the leaders of the company organization to employees in order to make them work by making highly achieved motivation in achieving corporate or organizational goals. Intrinsic rewards are rewards that are part of the work itself, the rewards include sense of completion, achievement, autonomy and growth, which means the ability to start or complete a work project is important to a number of individuals. Extrinsic rewards are rewards that come from work. The rewards include: money, status, promotion and respect. Ricky W. Griffin (2013: 491) describes the rewards as follows: An organizational reward system is the formal and informal mechanisms by which employee 
performance is defined, evaluated and rewarded. Rewards that are tied specifically to performance, of course, have the greats impact on enhancing both motivation and actual performance.

William B. Wether, and Keith Davis (2001: 240) define rewards as follows, "reward is what employees receive in exchange of their work. Whether hourly wages as periodic salaries, the personnel department usually designs and administrates employee reward". Based on the definition put forward it can be explained that reward is the wages received by workers in return for the work they provide either hourly wages or periodic salaries designed and managed by personnel unit. Intrinsic rewards are rewards that are part of the work itself, the rewards include sense of completion, achievement, autonomy and growth, which means that the ability to start or complete a work project is essential for a number of individuals.

Fred Luthans (2008:382) defines that, "a reward is simply something that the person who presents it deems to be desirable". Based on the definition it can be explained that reward is something that is expected to be accepted as desired. Next John W. Slocum, JR, dan Don Hellrigel (2011:136) state, "a reward is an event that an individual finds desirable or pleasing. An individual's culture influences whether a reward acts as a reinforcer". Rewards are an event that an individual wants or pleases. Individual culture affects whether rewards act as reinforcement.

Stephen P. Robbin, dan Timothy A. Judge (2011:456) state: These rewards can be either financial such as controlling pay rates, raises, and bonuses or nonfinancial, including recognition, promotion, interesting work assignments, friendly colleagues, and preferred work shifts or sales territories. Rewards can be money such as wage rates, salary increases, and bonuses or nonfinancial benefits, including recognition, promotion, engaging job assignments, friendly associates, and preferred work shifts or sales territories.

From the above description it can be synthesized that appreciation is the reward given by someone to others to complete the work, the achievement of organizational goals, with indicators; salary, bonus, and promotion.

\section{Research Methods:-}

This research applies descriptive quantitative approach from the outcomes result of the theory test through the measurement of research variables with numbers and performs data analysis with the statistical procedure (path analysis). Quantitative approach aims to show the relationship between variables, provide statistical descriptions, assess and forecast the results. The quantitative approach emphasizes the existence of variables as research objects and those variables must be defined in the operational form of each variable. The population in this study was 255 certified teachers of Junior High School in Pekanbaru City. Counting the number of samples using Slovin formula the number of samples obtained $=144$ teachers,

\section{Discussion Of Research Outcomes:-}

The results obtained after performing the model analysis were used as the basis for answering the hypothesis and drawing conclusions in this study. The explanation of the hypothetical answer can be described as follows:

\section{Positive Direct Influence of Leadership $\left(\mathrm{X}_{1}\right)$ on Performance (Y):-}

The coefficient value of leadership path to performance is 0.361 with a $t_{\text {count }}$ value of 4.410 . Because the value of $\mathrm{t}_{\text {count }}$ is greater than the value of $\mathrm{t}_{\text {table }}$ at $\mathrm{dk}=140$ for $\alpha=0.05$ that is equal to 1.98 , then, $\mathrm{H}_{0}$ is rejected and $\mathrm{H}_{1}$ is accepted, which means there is direct positive influence of leadership variable to significant performance variable.

The results of the first hypothesis analysis resulted in the finding that leadership had a positive direct effect on performance. Based on these findings, it can be concluded that performance is directly and positively influenced by leadership. Increased leadership will lead to improved performance. The results of this study are consistent with the opinion of some experts among whom is Yukl (2010: 463) who said that the relationship between task performance and leadership is very close and mutually reinforced; a strong concern for task performance is widely believed to be a requirement for effective leadership, even in some countries that do not have strong performance orientation values. That is, great attention to task performance is widely believed to be a requirement for effective leadership, even in some countries that do not have strong performance orientation values.

High performance of one's duties depends on the factors that influence him. In this case Jones (2002: 92) says that "Many things cause poor performance of tasks, among others: (1) personal ability, (2) manager ability, (3) process gap, (4) environmental problem, 5) personal situations, (6) motivation. 
A noble expression says that it is the leader who is responsible for the failure of the execution of a job, an expression that positions the leader in an organization in the most important position. Leadership is needed by human beings, because of some limitations and certain excesses in humans. Human capability is different, some have advantages and there are some who have limited ability to lead.

Thus the performance of lecturers tasks can be regarded as evidence of the work achievement realized in carrying out its duties and functions that cannot be separated from the control of the leadership system that reigns. Ideal leadership behavior is a behavior embraced by a figure who has the ability and ability to influence and direct subordinates to jointly do everything that becomes their duties and responsibilities, synergizing to realize the survival and success of educational institutions to reach the dreams (institutional vision).

\section{Positive Direct Inflence of Personality $\left(\mathbf{X}_{2}\right)$ to Performance (Y):-}

The coeficient value of personality path to performance is 0.284 with a $t_{\text {count }}$ value of 4.230 . Because the value of $\mathrm{t}_{\text {count }}$ is greater than the value of $\mathrm{t}_{\text {tableat }} \mathrm{dk}=140$ for $\alpha=0.05$ that is equal to 1.98 maka $\mathrm{H}_{0}$ ditolak dan $\mathrm{H}_{1}$ diterima, then $\mathrm{HO}$ is rejected and $\mathrm{H} 1$ is accepted, which means there is direct positive influence of personality variable to significant performance variable.

The results of the second hypothesis analysis resulted in the finding that personality has a direct positive effect on performance. Based on these findings it can be concluded that performance is directly affected positively by the personality. Increased personality will lead to improved performance. The results of this study are consistent with the opinions of several experts including Irwin A. Hyman and Pamela A. Snock (1999: 45) in their book "Dangerous School" which is sometimes also applied to impose penalties (sanctions) as a consequence of violations of the rules. Although sometimes it becomes controversial in applying disciplinary methods, it is trapped in the form of physical maltreatment and psychological maltreatment. With regard to the purpose of school discipline.

According to Luthans (2011: 152) regarding the influence of personality on performance: However, this is one area of personality where there is enough research evidence to conclude that conscientiousness should be given attention in understanding the impact that personality traits can have on job performance, job satisfaction, and work motivation, and pragmatically for personnel selection for most jobs.

However, this is one of personality areas where there is enough research evidence to conclude that conscientiousness which should be given attention in understanding the effects of personality traits can affect performance, job satisfaction, work motivation, and pragmatics for personal selection on most jobs.

According to Mcshane and Glinow (2012:41), personality affects performance, "conscientiousness and emotional stability (low neuroticism) stand out as the personality traits that best predict individual performance in almost every job group". Conscientiousness and emotional stability are the best personality traits in predicting individual performance in nearly every working group.

In the classroom, if a teacher is not able to apply discipline well then the student may become less motivated and gain a certain emphasis, and the learning atmosphere becomes less conducive to reach student learning achievement. Keith Devis said, "Discipline is management action to enforce organization standards" and therefore preventive and corrective discipline needs to be developed. Preventive discipline is the effort to encourage students to follow and follow the rules.

In the school internal environment, violations of school rules and regulations are often found ranging from minor level violations to high-level violations, such as: truancy, fights, cheating, robbery, theft and other forms of behavioral aberrations. Of course, all of them require prevention and mitigation, and this is the importance of school discipline. Student behavior is formed and influenced by various factors, including environmental factors, family and school. It cannot be denied that schooling is one of the dominant factors in shaping and influencing student behavior. In school a student interacts with teachers who educate and teach him. Attitudes, role models, deeds and speech of teachers are seen and heard and considered good by the students. 


\section{Positive Direct Inflence of Rewards $\left(\mathrm{X}_{3}\right)$ to Performance (Y):-}

The coeficient value of personality path to performance is 0.209 with a $t_{\text {count }}$ value of 2.530 . Because the value of $t_{\text {count }}$ is greater than the value of $t_{\text {table }}$ at $d k=140$ for $\alpha=0.05$ that is equal to 1.98 then $H_{0}$ is rejected and $H_{1}$ is accepted, which means there is direct positive influence of reward variable to the significant performance variable.

The results of the third hypothesis analysis resulted in the finding shows that rewards have a direct positive effect on performance. Based on the findings, it can be concluded that performance is directly affected positively by rewards. Rising rewards will lead to improved performance. The results of this study are consistent with the opinions of some experts such as Brown and Brown (2010: 23) who raised the importance of rewards in the process of education and to teach things as follows: (a) respect for authority/authority; discipline will awaken every student about his position, both inside and outside the classroom, for example his position as a student who must respect the teacher and principal, (b) efforts to instill cooperation; discipline in the teaching and learning process can be used as an effort to instill cooperation, either between students, students with teachers, and students with the environment, (c) the need to organize; discipline can serve as an effort to instill the need for organization in each student, (d) respect for others; with the discipline highly upheld in the teaching and learning process, every student will know and understand about his rights and obligations, and will respect and honor the rights and duties of others, (e) the need to do unpleasant things; in life we will always find pleasant and unpleasant things.Through discipline students are prepared to be able to deal with the things that are less or not pleasant in life in general and in the process of teaching and learning in particular, (f) introduces an example of undisciplined behavior; by giving an example of undisciplined behavior students are expected to avoid or be able to distinguish between rewarded and undisciplined behavior.

\section{Conclusion:-}

Based on the results of the analysis to the variables of leadership, personality, reward and performance, the following are the summary; (1) Leadership has a direct positive effect on performance. This means that good leadership of the principal can improve teacher performance. (2) Personality has a direct positive effect on performance. That is, the principal's flexible personality can help improve teacher performance. (3) Rewards have a positive direct effect on performance. That is, appropriate and good rewards can improve teacher performance.

\section{Bibliography:-}

1. Colquitt, Jason A. Jeffrey A. Lepine, Michael J. Wesson, Organizational Behavior improving performance and commitment in the workplace 4 edition. New York: McGraw-Hill, 2015.

2. Darling, L. \& Hammond. Teacher quality and student achievement: A Review of state policy evidence. Education Policy Analysis Archives. Volume 8 Number 1. 2000.

3. EFA Global Monitoring Report. EDUCATION FOR ALL 2000-2016: achievements and challenges. France: UNESCO. 2015

4. G. L Freeman, dkk, How to Pick Leaders, A Scientific Approach to Executive Selection, New York: Funk \& Wagnalls Company, 1950.

5. Griffin, Ricky W. Management principles and Practices 11 edition. Canada: South-western Cengange Learning, 2013.

6. Human Development Report 2016. Human Development for Everyone. UNDP. 2016

7. Irwin, Hayman A. and Snock A. Pamela. Dangerous School. USA: South Western Cengange Learning, 1999.

8. Jex, Steve M. Organizational Psychology. USA: John Wiley, 2002.

9. Kreithner, Robert and Angelo Kinicki, Organization Behavior. Irwin: McGraw-Hill International Edition, 2010.

10. Luthans, Fred. Organizational Behavior. New York: McGraw-Hill, 2008.

11. Luthans, Fred. Organizational Behavior: An Evidence-Based-Approach, Twelfth Edition. New York: McGrawHill 2011.

12. McShane, Steven and Marry Von Glinow, Organizational Behavior, 4th Edition. New York: McGrawHill/Irwin., 2008.

13. Millmore, Mike. Philip Lewis Mark Saunder, Strategic, Humen Resources Management London: Pearson , 2007.

14. Newstrom, John W. Organizational behavior human behavior at work 14 edition. New York: McGraw-Hill, 2015.

15. Robbins Stephen P. and Mary Coulter, Management, $11^{\text {th }}$ Edition. New York: Pearson Education, 2013. 
16. Robbins, Stephen P. Timothy A. Judge, Organizational Behavior. New Jersey: Pearson Education, Inc., Publishing as Prentice, 2011.

17. Robbins, Stephen. and Timothy A. Judge. Organizational Behavior. $15^{\text {th }}$ Edition. New Jersey: Pearson International Education. Inc. 2013.

18. Rue, Leslie W Lloyd L. Byars, Human Resource Management. New York: McGraw-Hill Companies, Inc. 2008.

19. Schacter, J. Teacher performance-based accountability: why, what and how. Santa Moica : Miken Family Foundation. 2006

20. Schermerhorn, John R. JR, Richard N. Osborn, Mary Uhl-Bien, James G. Hunt, Organizational Behavior 12 edition. Asia: Wiley, 2012.

21. Slocum, John W. JR. Don Hellrigel, Principles of Organizational Behavior 13 edition. USA: South-Western Cengange Learning, 2011.

22. Thierauf, Robert J. dkk, Management Principles A Contingency and Questionnaire Approach, New York: Jhon Wiley \& Sons, 1977.

23. Wether, WilliamB.KeithDavis,Personil Management and HumanResources. Koggahuka,Mc.GrawHill,2001.

24. Yulk, Gary. Leadership in Organizations 7 edition. England: Pearson, 2010. 